DOI: 10.21802/artm.2019.3.11.62.

УДК 616-092.12(616.61)+616-035

\title{
ПОРУШЕННЯ МЕТАБОЛІЗМУ ЩАВЛЕВОЇ КИСЛОТИ У ХВОРИХ НА ОКСАЛАТНИЙ НЕФРОЛІТІАЗ ТА СПОСОБИ ЇХ КОРЕКЦЇ̈
}

\section{Н.Т. Скоропад}

Івано-Франківський національний медичний університет, кафедра урології, м. Івано-Франківськ, Украӥна, ORCID ID: 0000-0002-0607-1155, e-mail:nazar.skoropad@gmail.com

Резюме. Сечокам'яна хвороба (СКХ) є однією з найпоширеніших патологій сечовидільної системи і займає друге місце у структурі урологічних захворювань після інфекцій сечовивідних шляхів. При аналізі хімічного складу конкрементів встановлено, що більшість (до 70-80 \% випадків) з них містить солі щавлевої кислоти та кальцій.

Мета дослідження: вивчити особливості порушень метаболізму щавлевої кислоти у хворих на оксалатний нефролітіаз, вдосконалити способи іх корекції та розробити ефективні схеми метафілактики оксалатного нефролітіазу.

У дослідженні взяли участь 120 людей, які були розділені на 3 групи в залежності від лікування після проведення дистанційної літотрипсії чи самостійного відходження конкременту верхніх сечових шляхів.

Концентрація гліколату в сечі хворих після комплексного лікування у III групі становили $620,2 \pm 49,2$ мкмоль/л, тобто практично досягла рівня здорових.

У I та II групах рівень гліколату у сечі був значно нижчим і не досягав фізіологічних норм, але спостерігалась тенденція до збільшення.

Включення в терапію антиоксидантного засобу - аргініну та комплексу вітамінів призводить до зниження рівня оксалурії до верхніх границь норми у III групі пацієнтів в сечі $456,91 \pm 37,70$ до $319,81 \pm 26,36$

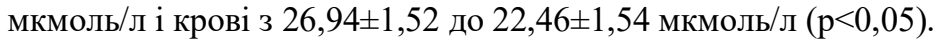

Спостерігалось зниження рівня кальцію у крові та сечі у пацієнтів I та II груп, хороших результатів досягнуто в III групі хворих при застосуванні в комплексній терапії антиоксиданта аргініну.

У результаті запропонованої метафілактики уролітіазу досягнуто збільшення концентрації цитрату в сечі та крові.

Результати метафілактичної терапії протягом 3 років показали, що у пацієнтів III групи кількість рецидивів оксалатного нефролітіазу був нижчий, ніж у I та II групах і становив $11,2 \%$ при показниках рецидивів 28,0 \% та 22,0 \% у I та II групах відповідно.

Ключові слова: оксалатний нефролітіаз, щавлева кислота, гліколат, цитрат, оксалат, L-аргінін.

Вступ та обгрунтування дослідження. Сечокам'яна хвороба (СКХ) є однією з найпоширеніших патологій сечовидільної системи і займає друге місце у структурі урологічних захворювань після інфекцій сечовивідних шляхів. У віковій структурі пацієнтів 3 уролітіазом переважають особи працездатного віку [1].

При аналізі хімічного складу конкрементів встановлено, що більшість (до $70-80 \%$ випадків) 3 них містить солі щавлевої кислоти та кальцій.

Незважаючи на велику кількість теорій, які пояснюють причини та механізми каменеутворення, все ще залишаються невирішеними багато питань, які потребують подальшого поглибленого вивчення. Ще однією актуальною проблемою, пов'язаною 3 нефролітіазом, є лікування та метафілактика, оскільки наявні на ринку численні препарати не завжди спроможні в повному об'ємі вплинути на патогенетичні ланки каменеутворення, тому частими є рецидиви захворювання, на високому рівні утримується первинна захворюваність.
Основною патогенетичною ланкою у розвитку СКХ є метаболічні порушення [2]. Проведено значну кількість робіт щодо вивчення стану каменеутворюючих метаболітів [3].

Деякі автори [4] вказують на низку припущень про наявність додаткових факторів у розвитку кальцій-оксалатного уролітіазу - активація ПОБ, що призводить до змін метаболізму і розвитку умов для уролітіазу.

Без вивчення метаболізму щавлевої кислоти неможливо оцінити стан каменеутворюючих субстанцій при оксалатному нефролітіазі, намітити шляхи їх корекції в метафілактиці.

Каменеутворюючими субстанціями при цьому виступають гліколат, цитрат, оксалат, кальцій, гліцерат. Вони є в основі щавлево-оксалатного метаболізму [5].

Гліколат - попередник гліоксилату, а в подальшому оксалат. При ушкодженні ферментів виникає патологічне збільшення концентрації оксалатів. При природженому ушкодженні - генетично обумовленому їх дефіциті, відбувається постійний ріст оксалату i 
його ендогенне нагромадження в організмі. Важливо, що ця група хворих значно менша, ніж хворі з набутою (вторинною) гіпероксалурією. Виникають такі стани внаслідок дії як ендогенних, так і екзогенних факторів [6], при цьому збережені і працюють основні ферменти печінки, хоча їх функція знижена.

Однією з основних каменеутворюючих субстанцій є оксалат. Екскреція оксалатів різко зростає тільки при первинній гіпероксалурії, що покладено в основу диференційного діагнозу типів гіпероксалурій, зокрема 3 вторинною. Вторинна гіпероксалурія нерідко протікає без підвищення добової екскреції оксалатів [7].

Мета дослідження: вивчити особливості порушень метаболізму щавлевої кислоти у хворих на оксалатний нефролітіаз, удосконалити способи їх корекції та розробити ефективні схеми метафілактики оксалатного нефролітіазу.

Матеріали і методи. Дослідження проводилось на базі урологічного відділення ЦМКЛ м. ІваноФранківськ. Було обстежено 120 хворих на оксалатний нефролітіаз віком від 20 до 65 років. Групу контролю склали 25 практично здорових осіб, які за віком i статтю були репрезентативні пацієнтам основної вибірки.

Усім пацієнтам після ДЛТ та спонтанного відходження каменя проводилась комплексна традиційна терапія згідно з протоколами МO3 України 3 додаванням сучасних метафілактичних заходів у лікуванні оксалатного нефролітіазу. Залежно від схеми терапії пацієнти були розділені на 3 групи.

Базова терапія включала застосування спазмолітичних середників: дротаверин 40 мг на добу, 7 днів, метамізол натрію - 500 мг, фенпіверину бромід - 0,02 мг, піпефенону гідро хлорид -2 мг на добу довенно краплинно; не стероїдних протизапальних препаратів: диклофенак натрію 75 мг на добу дом'язево, у разі інтенсивного нападу ниркової кольки на фоні відходження фрагментів каменя призначали декскетопрофен 50 мг, дом'язево, при виникненні ознак вторинного пієлонефриту - антибактеріальні середники групи фторхінолонів. Також у базову терапію входило призначення посиленого питного режиму та дієта.

Для поліпшення мікроциркуляції використовували антикоагулянти і дезагреганти - курантил 0,05 г на добу, 3 р або трентал 100 мг 3 рази на добу. Для стимуляції діурезу хворим призначали рослинні діуретики (комбінований фітопрепарат, 100 мл розчину містять: 100 мл водного екстракту (2:1), отриманого iз суміші лікарських рослин: хвоща польового стебла (Equisetumarvense) 570 мг, торичника червоного рослина (Spergulariarubra) 330 мг, болдо листя (Peumusboldus) 280 мг, опунції (кактус) інжирової квітки (Opuntiaficus-indica) 170 мг, залізниці вузьколистої квітки (Sideritisangustifolia) 170 мг, розмарину аптечного листя (Rosmarinusofficinalis) 170 мг, пальчатник (бермудська трава) коріння (Cynodondactylon) 170 мг, меліси аптечної листя (MelissOfficiflis) 170 мг; екстрагент - вода). У хворих зі змішаними каменями (оксалат+урат) на фоні гіпероксалурії, гіперурікемії та гіперурікозурії призначали цитратні суміші
(Блемарен, Ураліт) за схемою $з$ контролем рН сечі. Пацієнти, що отримували лікування за вищеописаною схемою, склали I групу.

Хворі II групи, окрім вищевказаної терапії, отримували вітамін А (ретинолу ацетат) орально після їди, вітамін В 6 (піридоксин) 100 мг, 2 рази на добу, а також препарат магнію - магне В6 1 табл., 3 рази на добу, 15 днів.

Численні метаболічні порушення спричинені вивільненням лізосомальних ферментів - рибонуклеаза, кисла та лужна фосфатаза. Гіпо- та гіпервітаміноз А призводить до ушкодження мітохондрій, підвищення активності ферментів, що змінюють проникність мембран і порушення формування їх мукополісахаридного компоненту, що викликає дегенеративні зміни та інтенсивне злущування епітелію, перебудови біошару клітинних мембран, вивільнення щавлевої кислоти в плазму крові i, як наслідок, оксалурії.

Піридоксин метаболізується в печінці у важливий кофактор для АГТ. На початку 1990 років стало відомо, що ефективність піридоксина пов'язана 3 наявністю залишкових рівнів каталітичної активності та імунореактивності АГТ. Виявлений факт, що ПГ-1 виникає на фоні дефіциту АГТ і проявляється в гепатоцитах, пояснює дію піридоксину.

Вітамін $\mathrm{B}_{6}$, надходячи в організм, фосфорилюється i перетворюється у піридоксин-5-фосфат i входить до складу ферментів, що виконують декарбоксилювання, трансамінування і рацемізацію амінокислот, а також ферментативне перетворення сіркоутримувальних та гідроксильваних амінокислот, приймає участь у обміні триптофану і біосинтезі сиротину.

$\mathrm{B}_{6}$ - головний коензим у трансамінуванні гліоксилату у гліцин і серин, чим знижує утворення щавлевої кислоти.

Хворі III групи (n=40) отримували традиційну терапію та вітамін А (ретинолу ацетат), вітамін B $_{6}$ (піридоксин), препарати магнію (магне B6) та Lаргіні 4,2 \% розчин по 100 мл внутрішньовенно краплинно 1 раз на добу 57 днів з переходом на пероральний прийом по 15 мл 2 рази на добу, 15 днів кожного місяця протягом 6-12 місяців.

Визначення рівнів гліколату, цитрату та оксалату проводили спектроскопічно за допомогою спектрофотоколориметра «Specol-210» при довжині хвилі 340 нм. Визначення рівня кальцію проводилось за загальноприйнятою методикою р за допомогою фотоелектроколориметра (КФК-3).

Ефективність проведеного лікування оцінювали за допомогою клінічних, лабораторних, біохімічних, бактеріологічних критеріїв. Обстеження проводилось у клінічних умовах та в динаміці - амбулаторно.

Контроль рецидивів каменя проводився за допомогою УЗД та рентгенологічно (за показаннями).

Результати дослідження та їх обговорення. Динаміка показників метаболізму щзвлевої кислоти. Ланцюг росту та утворення щавлевої кислоти з подальшою гіпероксалурією включає порушення метаболізму гліколату, гліцерату, ферменту Дгліцератдегідрогенази та оксалату. 
Концентрація гліколату в сечі хворих після комплексного лікування у III групі становили $620,2 \pm 49,2$ мкмоль/л, тобто практично досягла рівня здорових (табл. 1).

У I та II групах рівень гліколату у сечі був значно нижчим і не досягав фізіологічних норм (табл. 1), але спостерігалась тенденція до збільшення.

Динаміка змін кониентрації оксалатів. Для проведення патогенетично обгрунтованої метафілак- тики оксалатного нефролітіазу необхідно враховувати всі основні фактори ризику каменеутворення, одним із яких $є$ гіпероксалурія. Вивчити літогенний вплив оксалату, динаміку змін концентрації у крові та сечі на фоні протирецидивної терапії $є$ важливим фактором.

Рівень оксалату у сечі та крові вивчали у групах згідно з призначеною терапією.

Динаміка вмісту гліколату у сечі хворих на оксалатний нефролітіаз

\begin{tabular}{|l|c|c|c|c|}
\hline Показники, кмоль/л & I група $(\mathrm{n}=40)$ & II група $(\mathrm{n}=40)$ & III група $(\mathrm{n}=40)$ & 3дорові $(\mathrm{n}=25)$ \\
\hline До лікування & $548,2 \pm 36,8$ & $550,0 \pm 36,9$ & $561,4 \pm 48,9$ & $620,6 \pm 62,14$ \\
\hline Після лікування & $575,9 \pm 49,2$ & $568,5 \pm 46,4$ & $620,2 \pm 49,2^{*}$ & - \\
\hline
\end{tabular}

Примітка: * p<0,05 - достовірність різниці показників до і після лікування в III групі.

Таблиця 2

Динаміка вмісту оксалату в крові та сечі хворих на оксалатний нефролітіаз

\begin{tabular}{|c|c|c|c|c|c|}
\hline & \multirow{2}{*}{$\begin{array}{l}\text { Показник, } \\
\text { мкмоль/л }\end{array}$} & \multicolumn{3}{|c|}{ Хворі } & \multirow{2}{*}{ Здорові $(\mathrm{n}=25)$} \\
\hline & & I група $(\mathrm{n}=40)$ & II група $(\mathrm{n}=40)$ & III група (n=40) & \\
\hline \multirow{2}{*}{ 巳 } & До лікування & $470,30 \pm 34,60 * *$ & $487,51 \pm 36,90 * *$ & $456,91 \pm 37,70$ & \multirow[t]{2}{*}{$305,28 \pm 26,45$} \\
\hline & $\begin{array}{l}\text { Після } \\
\text { вання }\end{array}$ & $389,81 \pm 22,64$ & $408,87 \pm 30,26$ & $319,81 \pm 26,36$ & \\
\hline \multirow[b]{2}{*}{ 竞 } & До лікування & $27,06 \pm 1,66$ & $25,30 \pm 1,76$ & $26,94 \pm 1,52$ & \multirow[t]{2}{*}{$21,14 \pm 12,6$} \\
\hline & $\begin{array}{ll}\text { Після } & \text { ліку- } \\
\text { вання }\end{array}$ & $24,86 \pm 1,64$ & $27,48 \pm 1,58$ & $22,46 \pm 1,54$ & \\
\hline
\end{tabular}

Примітка: **p<0,05 - достовірність різниці показників між групами.

Метафілактичні заходи у пацієнтів I та II груп досягають певних покращень, проте їх ефективність недостатня, зниження оксалурії при цьому статистично не доведене (табл. 2).

Включення в терапію антиоксидантного засобу - аргініну та комплексу вітамінів призводить до зниження рівня оксалурії до верхніх границь норми у III групі пацієнтів в сечі 456,91 $\pm 37,70$ до $319,81 \pm 26,36$

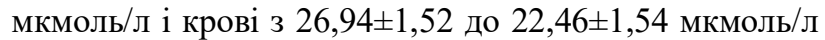
$(\mathrm{p}<0,05)$ (табл. 2).

Динаміка змін кониентрації кальціюо в крові та сечі хворих на оксалатний нефролітіаз. Кальцій у формуванні ниркових каменів займає одну з основних ніш і близько 70,0 \% всіх конкрементів мають у своєму складі кальцій.
Іони кальцію в організмі людини відіграють важливу роль. У процесі каменеутворення необхідно вивчити та порівняти його рівень у крові та сечі до та після проведення лікувальних заходів.

Наведені показники в таблиці 3 вказують на певне зниження рівня кальцію у крові та сечі у пацієнтів I та II груп, хороших результатів досягнуто в III групі хворих при застосуванні в комплексній терапії антиоксиданту аргініну. Діапазон коливання кальцію

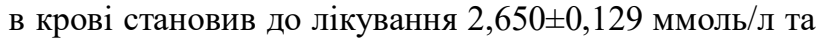
$2,160 \pm 0,128$ ммоль/л - після лікування. Рівень кальцію в сечі до лікування становив $6,740 \pm 0,322$ ммоль/л, а після - 5,086 $\pm 0,310$ ммоль/л.

Динаміка змін концентрації кальцію в крові та сечі хворих на оксалатний нефролітіаз

\begin{tabular}{|c|c|c|c|c|c|}
\hline & \multirow{2}{*}{$\begin{array}{l}\text { Показник, } \\
\text { ммоль/л }\end{array}$} & \multicolumn{3}{|c|}{ Хворі } & \multirow{2}{*}{ Здорові $(\mathrm{n}=25)$} \\
\hline & & I група $(n=40)$ & II група $(n=40)$ & III група (n=40) & \\
\hline \multirow{2}{*}{ 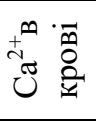 } & До лікування & $2,710 \pm 0,126$ & $2,841 \pm 0,139$ & $2,650 \pm 0,129$ & \multirow[t]{2}{*}{$2,24 \pm 0,120$} \\
\hline & $\begin{array}{l}\text { Після } \\
\text { вання }\end{array}$ & $2,371 \pm 0,120$ & $2,520 \pm 0,128$ & $2,160 \pm 0,128$ & \\
\hline \multirow{2}{*}{ 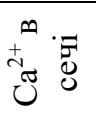 } & До лікування & $6,820 \pm 0,462$ & $7,060 \pm 0,494$ & $6,740 \pm 0,322$ & \\
\hline & $\begin{array}{ll}\text { Після } & \text { ліку- } \\
\text { вання }\end{array}$ & $5,620 \pm 0,306$ & $5,690 \pm 0,352$ & $5,086 \pm 0,310$ & \\
\hline
\end{tabular}

Примітка: $\mathrm{p}<0,05$ - достовірність різниці показників між групами.

Динаміка рівня цитрату в крові та сечі. У роботах багатьох авторів вказується, що гіпоцитратурія є одним із важливих елементів інгібіторної активності сечі, гіперкристалурії, а в даному випадку гіпероксалурії, є фактором ризику каменеутворення.
У результаті запропонованої метафілактики уролітіазу досягнуто збільшення концентрації цитрату в сечі та крові (табл. 4). Ріст рівня цитрату можна пояснити зниженням витрат цитрату за рахунок зменшення концентрації оксалатів у крові та сечі, що, в свою чергу, підвищує інгібіторну активність сечі. 
Таблиця 4

Вміст цитрату у крові та сечі хворих на оксалатний нефролітіаз

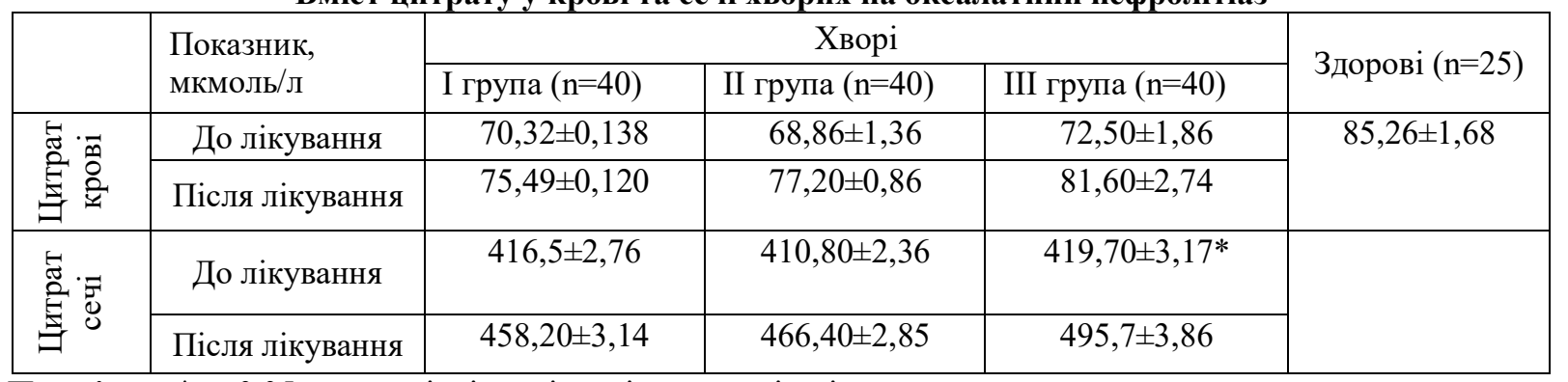

Примітка: * p $<0,05$ - достовірність різниці показників між групами.

Висновки. Призначення запропонованої схеми лікування забезпечувало зниження рівня гліколату в сечі практично до рівня здорових

Включення в терапію антиоксидантного засобу - аргініну та комплексу вітамінів призводить до зниження рівня оксалурії до верхніх границь норми у крові та сечі.

Застосування в комплексній терапії антиоксиданта аргініну сприяло достовірному зниженню рівня кальцію в крові та сечі у хворих на оксалатний нефролітіаз.

У результаті запропонованої метафілактики уролітіазу досягнуто збільшення концентрації цитрату в сечі та крові за зниженням витрат цитрату.

Результати метафілактичної терапії протягом 3 років показали, що у пацієнтів III групи кількість рецидивів оксалатного нефролітіазу був нижчий, у I та II групах і становив 11,2 \% при показниках рецидивів 28,0 \% та 22,0 \% у I та II групах відповідно.

\section{References:}

1. Saidakova NO, Shuliak OV, Shylo VM, Dmytryshyn SP, Konovalova HYe. Sechokamiana khvoroba: stan ta problemni pytannia nadannia spetsializovanoi dopomogy naselenniu v m. Kyiv. Urologija. 2018; 22(1):33-40. [in Ukrainian].

2. Wong YV, Cook P, Somani BK. The Association of Metabolic Syndrome and Urolithiasis. International Journal of Endocrinology. [Internet]. 2015. Available from: http://dx.doi.org/10.1155/2015/570674

3. Alelign T, Petros B. Kidney Stone Disease: An Update on Current Concepts. Adv Urol. [Internet]. 2018. Available from: https://doi.org/10.1155/2018/3068365

4. Ferraro PM, Taylor EN, Gambaro G, Curhan, GC. Dietary and Lifestyle Risk Factors Associated with Incident Kidney Stones in Men and Women. The Journal of Urology. 2017; 198(4):858-863.

5. Liebow A, Li X, Racie T, Hettinger J, Bettencourt $\mathrm{BR}$, Najafian $\mathrm{N}$ et al. An Investigational RNAi Therapeutic Targeting Glycolate Oxidase Reduces Oxalate Production in Models of Primary Hyperoxaluria. J Am Soc Nephrol. 2017; 28:494-503.

6. Dutta Ch, Avitahl-Curtis N, Pursell N, Larsson Cohen M, Holmes B, Diwanji R et al. Inhibition of Glycolate Oxidase With Dicer-substrate siRNA Reduces Calcium Oxalate Deposition in a Mouse Model of Primary Hyperoxaluria Type 1. Mol Ther. 2016, Apr; 24(4):770-778.
7. Bhasin B, Melda Ürekli H, Atta MG. Primary and secondary hyperoxaluria: Understanding the enigma World J Nephrol. 2015, May 6; 4(2):235-244.

\section{УДК 616-092.12(616.61)+616-035 \\ НАРУШЕНИЯ МЕТАБОЛИЗМА ЩАВЕЛЕВОЙ КИСЛОТЫ У БОЛЬНЫХ ОКСАЛАТНЫМ НЕФРОЛИТИАЗОМ И СПОСОБЫ ИХ КОРРЕКЦИИ}

\section{Н.Т. Скоропад}

\begin{abstract}
Ивано-Франковский национальный медицинский университет, кафедра урологии, 2. Ивано-Франковск, Украина, ORCID ID: 0000-0002-0607-1155, e-mail:nazar.skoropad@gmail.com
\end{abstract}

Резюме. Мочекаменная болезнь (МКБ) является одной из самых распространенных патологий мочевыделительной системы и занимает второе место в структуре урологических заболеваний после инфекций мочевыводящих путей. При анализе химического состава конкрементов установлено, что большинство (до 70-80 \% случаев) из них содержит соли щавелевой кислоты и кальций.

Цель исследования: изучить особенности нарушений метаболизма щавелевой кислоты у больных на оксалатный нефролитиаз, усовершенствовать способы их коррекции и разработать эффективные схемы метафилактики оксалатного нефролитиаза.

Обследовано 120 пациентов с оксалатным нефролитиазом в возрасте от 20 до 65 лет. Контрольная группа состояла из 25 здоровых людей.

Все пациенты после экстракорпоральной литотрипсии и самопроизвольного отхождения камней прошли комплексную терапию по протоколам Министерства здравоохранения Украины с добавлением современных метафилактических мер при лечении оксалатного нефролитиаза. В зависимости от лечения пациенты были разделены на 3 группы.

Концентрация гликолата в моче больных после комплексного лечения в III группе составляли $620,2 \pm$ 49,2 мкмоль / л, то есть практически достигла уровня здоровых.

В I и II группах уровень гликолата в моче был значительно ниже и не достигал физиологических норм, но наблюдалась тенденция к увеличению. 
Включение в терапию антиоксидантного средства - аргинина и комплекса витаминов приводит к снижению уровня оксалурии к верхним границам нормы в III группе пациентов в моче 456,91 $\pm 37,70$ до $319,81 \pm 26,36$ мкмоль/л и крови с $26,94 \pm 1,52$ до $22,46 \pm 1,54$ мкмоль/л $(\mathrm{p}<0,05)$.

Наблюдалось снижение уровня кальция в крови и моче у пациентов I и II групп, хороших результатов достигнуто в III группе больных при применении в комплексной терапии антиоксиданта аргинина.

В результате предложенной метафилактики уролитиаза достигнуто увеличение концентрации цитрата в моче и крови.

Результаты метафилактической терапии в течение 3 лет показали, что у пациентов III группы количество рецидивов оксалатного нефролитиаза был ниже, чем в I и II группах и составил 11,2 \% при показателях рецидивов 28,0 \% и 22,0 \% в I и II группах соответственно.

Ключевые слова: оксалатный нефролитиаз, щавелевая кислота, гликолят, цитрат, оксалат, Lаргинин.

\section{UDC 616-092.12(616.61)+616-035 \\ OXALIC ACID METABOLISM DISORDERS IN PATIENTS WITH OXALATE NEPHROLITHIASIS AND WAYS OF CORRECTION}

\author{
N.T. Skoropad \\ Ivano-Frankivsk National Medical University, \\ Department of Urology, Ivano-Frankivsk, Ukraine, \\ ORCID ID: 0000-0002-0607-1155, \\ e-mail: nazar.skoropad@gmail.com
}

Abstract. Urolithiasis is one of the most common pathologies of the urinary system and ranks second in the structure of urological diseases after urinary tract infections. In the analysis of the chemical composition of the concretions it is found that the majority (up to 70$80 \%$ of cases) of them contain salts of oxalic acid and calcium. Numerous metabolic disorders are caused by the release of lysosomal enzymes - ribonuclease, acidic and alkaline phosphatase.

The aim of the study was to define the peculiarities of disorders of oxalic acid metabolism in patients with oxalate nephrolithiasis, to improve the methods of their correction and to develop effective schemes of metaphylactics of oxalate nephrolithiasis. Hypo- and hypervitaminosis A lead to mitochondrial damage, increased activity of enzymes that change in membrane permeability and violation of their torment polysaccharide component causing degenerative changes and intense desquamation of epithelial cell membranes adjustment, release oxalic acid in blood plasma, and consequently cause oxasaluria.

120 patients with oxalate nephrolithiasis aged 20 to 65 years were examined. The control group consisted of 25 healthy individuals who were representative to the patients in the main sample by age and gender.

All patients after extracorporeal lithotripsy and spontaneous stone removal underwent complex traditional therapy according to the protocols of the Ministry of Health of Ukraine, with the addition of modern metaphylactic measures in the treatment of oxalate nephrolithiasis. Patients were prescribed herbal diuretics to stimulate diuresis (combined phytopreparation, $100 \mathrm{ml}$ of solution containing: $100 \mathrm{ml}$ of an aqueous extract (2: 1) obtained from a mixture of medicinal plants: horsetail of a field stalk (Equisetumarvense) $570 \mathrm{mg}$, bulb of a red plant (Spergulariar $330 \mathrm{mg}$, bald leaves (Peumusboldus) 280 $\mathrm{mg}$, prickly pear (cactus) fig flower (Opuntiaficus-indica) $170 \mathrm{mg}$, narrow-leaved flower railway (Sideritisangustifolia) $170 \mathrm{mg}$, rosemary pharmacy leaves (Rosmarinusofficinalis) $170 \mathrm{mg}$, palmchat (170) $\mathrm{mg}$, pharmacy leaf lemon balm (MelissOfficiflis) $170 \mathrm{mg}$; extractant water. ). In patients with mixed stones (oxalate + urate) on the background of hyperoxaluria, hyperuricemia and hyperuricosuria was prescribed citrate mixtures (Blemaren, Uralite) according to the scheme with control of urine $\mathrm{pH}$. ed into 3 groups.

Depending on the regimen, patients were divid-

The concentration of glycolate in the urine of patients after complex treatment in group III amounted to $620,2 \pm 49,2 \mu \mathrm{mol} / 1$, practically reached the level of healthy.

In groups I and II, the level of glycolate in urine was much lower and did not reach physiological norms, but there was a tendency to increase.

The inclusion of the antioxidant agent - arginine and the complex of vitamins in therapy leads to a decrease in the level of oxaluria to the upper limits of norm in group III of patients in urine $456,91 \pm 37,70$ to 319,81 $\pm 26,36 \mu \mathrm{mol} / 1$ and blood from $26,94 \pm 1.52$ to $22.46 \pm$ $1.54 \mu \mathrm{mol} / 1(\mathrm{p}<0.05)$. There was a decrease if calcium levels in blood and urine in patients of groups I and II, good results were achieved in group III patients due to the use of arginine antioxidant in combined therapy.

As a result of the proposed metaphylactic tactics, an increase in the concentration of citrate in the urine and blood is achieved.

The results of metaphylactic therapy for 3 years showed that the number of relapses of oxalate nephrolithiasis was lowest in patients of group III $(11.2 \%)$, compared to results of groups I and II where the recurrence rates were $28.0 \%$ and $22.0 \%$.

Keywords: oxalate nephrolithiasis, oxalic acid, glycolate, citrate, oxalate, L-arginine.

Стаття надійшла в редакцію 15.09.2019 р. 